\title{
Clinical significance of androgen receptor expression in triple negative breast cancer-an immunohistochemistry study
}

\author{
YA-XUAN LIU, KE-JING ZHANG and LI-LI TANG \\ Department of Breast Surgery, Breast Cancer Prevention and Clinical Research Center, \\ Xiangya Hospital Central South University, Changsha, Hunan 410008, P.R. China
}

Received February 14, 2017; Accepted January 26, 2018

DOI: $10.3892 / \mathrm{ol} .2018 .8548$

\begin{abstract}
Androgen receptor (AR) is closely associated with the occurrence and progression of breast cancer; however, the clinical significance of it in triple negative breast cancer (TNBC) has been controversial. There is a limited amount of research regarding the effect of neoadjuvant chemotherapy on AR expression. By examining the expression of AR in patients with TNBC, the aim of the present study is to explore the clinical significance of $\mathrm{AR}$ and provide evidence for AR-directed treatment in TNBC. A total of 188 patients with primary TNBC with complete medical records were included in this retrospective study. Tumor sections from 41 patients $(21.8 \%)$ were positive for $\mathrm{AR}$, which was more often detected in small tumors $(\mathrm{P}=0.042)$ and cases with no lymph node involvement $(\mathrm{P}=0.032)$. Among them, 102 were treated with neoadjuvant chemotherapy (NAC). A total of 17 patients (16.7\%) exhibited pathological complete response. However, the patient response was irrelevant to AR expression. Matched pathological tissues before and after NAC were collected for 49 cases, suggesting an enrichment of AR-expressing tumors following chemotherapy $(\mathrm{P}=0.008)$. Further analysis indicated that AR expression had no correlation with the disease-free and overall survival of patients with general TNBC; rather, it predicted a poor survival of the patients with stage III TNBC in comparison with those at earlier stages $(\mathrm{P}=0.035)$. AR expression occurs more often in small TNBC tumors or in cases with no lymph node metastasis. It is associated with a poor prognosis of the patients with advanced stages of tumors.
\end{abstract}

Correspondence to: Professor Li-Li Tang, Department of Breast Surgery, Breast Cancer Prevention and Clinical Research Center, Xiangya Hospital Central South University, 87 Xiangya Road, Changsha, Hunan 410008, P.R. China

E-mail: tlli77@126.com

Key words: breast cancer, triple negative breast cancer, androgen receptor prognosis

\section{Introduction}

Breast cancer is the most prevalent and lethal malignancy among females worldwide (1). In 2018, 1,735,350 incident breast cancer cases are estimated to be diagnosed in the United States of America and 609,640 associated mortalities are anticipated (2). Breast cancer is highly heterogeneous in biological and clinical features, and multimodality measures, including surgery, endocrinotherapy, chemotherapy and radiotherapy have been developed for treatment, in the past few decades. Precision medicine arising in recent years has been significant in prolonging the survival of patients with specific genetic backgrounds and improving their quality of life (3).

Molecular diagnosis allows the stratification of breast cancer into four major subtypes based on the expression of estrogen receptor (ER), progesterone receptor (PR) and human epidermal growth factor receptor 2 (HER2) (4). Targeted therapies blocking the functions of ER or HER2 have exhibited prominent clinical benefits in patients with tumors positive for the ER, or HER2 receptors $(5,6)$. However, the clinical outcome of a large number of patients remains poor due to $30-40 \%$ of breast cancer cases being ER-negative and $70-80 \%$ being HER2-negative. Furthermore, 15-20\% of patients with triple negative breast cancer (TNBC) are negative for ER, PR and HER2 (7). TNBC is a distinct subtype of breast cancer that is characterized by frequent recurrence and metastasis (8), and chemotherapy is currently the only available systemic treatment approach. Chemotherapy has been effective; however, it results in strong side effects and high costs (9). In general, patients who achieve pathological complete responses (pCR) following neoadjuvant chemotherapy (NAC) typically have a favorable prognosis (10). However, at present, it is unclear what clinicopathological and molecular features may be used to identify this subpopulation of patients.

Androgen receptor (AR) is a nuclear receptor, which, upon the binding of androgen, forms a hormone-receptor complex that acts on the androgen response elements of target genes to mediate gene transcription (11). AR is widely expressed in human tissues, including testis, ovary and breast (12). Deletion of the AR-encoding gene in mice leads to abnormal mammary gland development and growth retardation (13). AR has drawn increasing attention in the management of breast 
cancer in recent years, as AR is expressed in $\sim 80 \%$ of primary breast cancers and often at a higher level in comparison with ER $(14,15)$. This AR alteration explains the clinical benefit rate of $20-25 \%$ in patients with breast cancer treated by testosterone, as demonstrated in the 1970s (16). Testosterone was later replaced with tamoxifen and aromatase inhibitors, due to its masculinizing effects (17). These ER-modulating drugs have been widely used; however, their efficacy can be limited by patient intolerance $(18,19)$. The observation that aromatase inhibitors elevate androgen levels highlights the potential significance of AR-modulating agents (20).

AR is upregulated in up to $53 \%$ of TNBC tumors $(14,21,22)$. There are six subcategories of TNBC classified by gene expression profiles: Basal-like 1, basal-like 2, immunomodulatory, mesenchymal, mesenchymal stem-like and luminal androgen receptor (LAR) (23). The LAR-type tumors are usually abundant with AR upregulation (7). Unsurprisingly, a preclinical study demonstrated that LAR-type breast cancer cell lines are sensitive to AR antagonists (24). These findings suggest AR may be a valuable prognostic marker in TNBC.

In order to explore the clinical significance of AR in TNBC, the expression of AR in 188 TNBC patients was examined and its association with the outcome of 102 patients who were treated with NAC was assessed. Using a cohort of 49 patients with tissue samples collected prior to and following NAC, the effect of NAC on AR expression in TNBC was also studied, and the prognosis function of AR in correlation with survival rates was evaluated.

\section{Materials and methods}

Ethical approval. The present study was approved by the Research Ethics Committee of Xiangya Hospital Central South University (Changsha, China; approval no. 201303083). Written informed consent was obtained from all patients to include their data in this retrospective study.

Patient selection. A total of 188 patients, aged $49.42 \pm 9.73$ years old (mean \pm standard deviation) with primary TNBC who underwent treatment at Xiangya Hospital, Central South University, between July 2011 and July 2014 were included. The patients were chosen based on the pathological features, therapeutic approaches, metastatic status, and availability of a complete medical record, which included age, menstrual status, body mass index (BMI), relevant family history, tumor grade and size, lymph node involvement, clinical stage, Ki-67 expression, and clinical follow-up information. All patients were diagnosed to have invasive ductal carcinoma with no systemic metastases. Expression of HER2 was re-evaluated due to the positive threshold of the HER-2 testing was $10 \%$, reduced from $30 \%$ in 2009, and in fluorescent in situ hybridization for positivity, the HER2/CEP17 ratio is $\geq 2$, or HER2 copy number is $>6$ signals per cell (25). HER2-positive patients were excluded from the present study. Of the total 188 patients, 102 were treated with NAC, which included 3-4 cycles (3 weeks/cycle) of docetaxel $\left(75 \mathrm{mg} / \mathrm{m}^{2}\right)$, pirarubicine $\left(50 \mathrm{mg} / \mathrm{m}^{2}\right)$, or cyclophosphamide $\left(500 \mathrm{mg} / \mathrm{m}^{2}\right)$. Matched preand post-chemotherapy tissues were available for 49 patients. The pre- and post-chemotherapy tissues were collected by needle core biopsy and surgical excision, respectively.
Immunohistochemistry. Immunohistochemical analysis was performed following a commonly used protocol outlined by the study of Shi et al (26) with minor modifications. Briefly, tissues were fixed, paraffin-embedded, and dissected into 4- $\mu \mathrm{m}$ thick sections. Serial sections were dewaxed in xylene, rehydrated by a series of decreasing percentages of ethanol in water, and rinsed with PBS. Antigen retrieval was performed by heating the sections in a $95^{\circ} \mathrm{C}$ water bath in the presence of EDTA in a microwave for $20 \mathrm{~min}$. The slides were additionally treated with $3 \%$ hydrogen peroxide (reagent 1; catalog no. PV-9000; ZSGB-BIO; OriGene Technologies, Beijing, China) and blocked with normal goat serum (ZSGB-BIO; OriGene Technologies) for $40 \mathrm{~min}$ in room temperature. The tissue sections were then incubated overnight at $4^{\circ} \mathrm{C}$ with a monoclonal mouse anti-AR (dilution 1:50; catalog no. ab9474; Abcam, Cambridge, UK). The next day, the slides were incubated with an undiluted polymer helper (reagent 2; catalog no. PV-9000; ZSGB-BIO; OriGene Technologies) for $20 \mathrm{~min}$ at $37^{\circ} \mathrm{C}$, followed by staining with appropriate undiluted secondary antibodies (reagent 3-mouse, catalog no. PV-9000, ZSGB-BIO; OriGene Technologies) conjugated with poly-peroxidase for $20 \mathrm{~min}$ at $37^{\circ} \mathrm{C}$. Color was developed using diaminobenzidine as a chromogen. All slides were assessed and scored by pathologists (light microscope; Leica Microsystems GmbH, Wetzlar, Germany; magnifications, $\mathrm{x} 100$ and $\mathrm{x} 400$ ). By using the double-blind reading, pathologists selected 10 high magnification fields of view (x400) randomly, and counted $>100$ cells in each field. Staining of AR was considered positive when $\geq 1 \%$ of the tumor cell nuclei were stained.

Prognostic analysis. When accessible, patients were followed up monthly until mortality or July 2016, the cutoff date for data collection. Complete follow-up information was obtained for 188 patients by outpatient review and phone communication. The patient data, including dates of treatment and first recurrence, metastatic status, and the TNBC-associated mortality were used to assess the overall (OS) and disease-free survivals (DFS). OS was defined as the period of time from the date of surgery to the date of mortality associated with breast cancer or the last follow-up time. DFS was defined as the period of time from the date of surgery to the date of first recurrence, metastasis, or mortality associated with breast cancer.

Statistical analysis. The data were analyzed by Statistical Package for Social Sciences software version 22.0 (IBM Corp., Armonk, NY, USA). Associations between AR expression, and clinicopathological features and the outcome of NAC were assessed using $\chi^{2}$ or Fisher's exact tests. A Kaplan-Meier estimator and log-rank test were used to assess the patient survival rate. A multivariate analysis using the Cox proportional hazard regression model was performed to assess prognosis. $\mathrm{P}<0.05$ was considered to indicate a statistically significant difference.

\section{Results}

AR is expressed in TNBC. AR expression in TNBC was assessed by immunohistochemistry (Table I). Among the 
Table I. Association between AR expression and clinicopathological characteristics in 188 patients with TNBC.

\begin{tabular}{|c|c|c|c|c|}
\hline \multirow[b]{2}{*}{ Characteristics } & \multicolumn{2}{|c|}{$\mathrm{AR}$} & \multirow[b]{2}{*}{$\chi^{2}$} & \multirow[b]{2}{*}{ P-value } \\
\hline & Positive (\%) & Negative (\%) & & \\
\hline \multicolumn{5}{|l|}{ Age (years) } \\
\hline$\leq 50$ & $24(21.6)$ & 87 (78.4) & 0.006 & 0.941 \\
\hline$>50$ & $17(22.1)$ & $60(77.9)$ & & \\
\hline \multicolumn{5}{|l|}{ Menstrual status } \\
\hline Pre-menopause & $27(21.8)$ & $97(78.2)$ & $<0.001$ & 0.987 \\
\hline Post-menopause & $14(21.9)$ & $50(78.1)$ & & \\
\hline \multicolumn{5}{|l|}{ BMI } \\
\hline$<24$ & $28(23.5)$ & $91(76.5)$ & 0.563 & 0.453 \\
\hline$\geq 24$ & $13(18.8)$ & $56(81.2)$ & & \\
\hline \multicolumn{5}{|l|}{ Family history } \\
\hline No & $36(23.4)$ & 118 (76.6) & 1.228 & 0.268 \\
\hline Yes & $5(14.7)$ & $29(85.3)$ & & \\
\hline \multicolumn{5}{|l|}{ Tumor grade } \\
\hline I-II & $29(21.5)$ & $106(78.5)$ & 0.030 & 0.862 \\
\hline III & $12(22.6)$ & $41(77.4)$ & & \\
\hline \multicolumn{5}{|l|}{ Tumor size $(\mathrm{cm})$} \\
\hline$\leq 5$ & $37(25)$ & $111(75)$ & 4.155 & 0.042 \\
\hline$>5$ & $4(10)$ & $36(90)$ & & \\
\hline \multicolumn{5}{|c|}{ Lymph node metastasis } \\
\hline No & $27(28.1)$ & $69(71.9)$ & 4.590 & 0.032 \\
\hline Yes & $14(15.2)$ & $78(84.8)$ & & \\
\hline \multicolumn{5}{|l|}{ Clinical stage } \\
\hline I-II & $31(24.4)$ & $96(75.6)$ & 1.553 & 0.213 \\
\hline III & $10(16.4)$ & $51(83.6)$ & & \\
\hline \multicolumn{5}{|l|}{$\mathrm{Ki}-67$} \\
\hline$<14$ & $10(23.3)$ & $33(76.7)$ & 0.068 & 0.794 \\
\hline$\geq 14$ & $31(21.4)$ & 114 (78.6) & & \\
\hline
\end{tabular}

$\mathrm{AR}$, androgen receptor; TNBC, triple negative breast cancer; BMI, body mass index.

188 patients diagnosed with TNBC, tumor sections from 41 patients $(21.8 \%)$ stained positively for AR (AR ${ }^{+}$; Fig. $\left.1 \mathrm{~A}\right)$, while others exhibited no evident AR expression $\left(\mathrm{AR}^{-}\right.$; Fig. 1B). Statistical analysis indicated a significant association between AR expression and smaller tumors $(\mathrm{P}=0.042$; Table I), suggesting AR was likely expressed during the early stage of cancer progression. Consistently, the AR protein expression was significantly associated with the localization of the tumors; TNBC with no lymph node metastases more likely expressed AR ( $\mathrm{P}=0.032$, Table I). No significant association between AR expression with age, menstrual status, BMI, family history, tumor grade, clinical stage or Ki-67 expression was identified (Table I).

AR expression has no significant effect on the outcome of chemotherapy. Of the 188 patients, 102 were treated with NAC (Table II). Their responses were assessed according to the guideline of the response evaluation criteria in solid tumors (27) and are summarized in Table II, together with the clinicopathological features of the patients, in order to identify the factors that affect response to NAC. The results indicated that a higher BMI was the only parameter predicting $\mathrm{pCR}$. Among 102 patients treated by NAC, 20 (19.6\%) were positive for AR prior to treatment whereas the other 82 were negative (Table II). Following chemotherapy, 5/20 AR-positive patients (25\%) exhibited pCR, while 12/82 AR-negative patients (14.6\%) exhibited pCR. However, no statistically differences were identified between the two cohorts $(\mathrm{P}=0.316)$.

A total of 49/102 patients underwent post-chemotherapy surgery to remove residual tumors, which were sampled ex vivo for immunohistochemistry analysis. The results indicated that tumors from $21 / 49$ patients (42.9\%) expressed AR (Table III). Which was significantly higher than the pre-chemotherapy data (19.6\%) (Table III), suggesting an enrichment of AR-expressing tumors following chemotherapy $(\mathrm{P}=0.008)$. As shown in Table III, 12 patients with AR-negative tumors were identified to have AR-positive nodules following chemotherapy. 

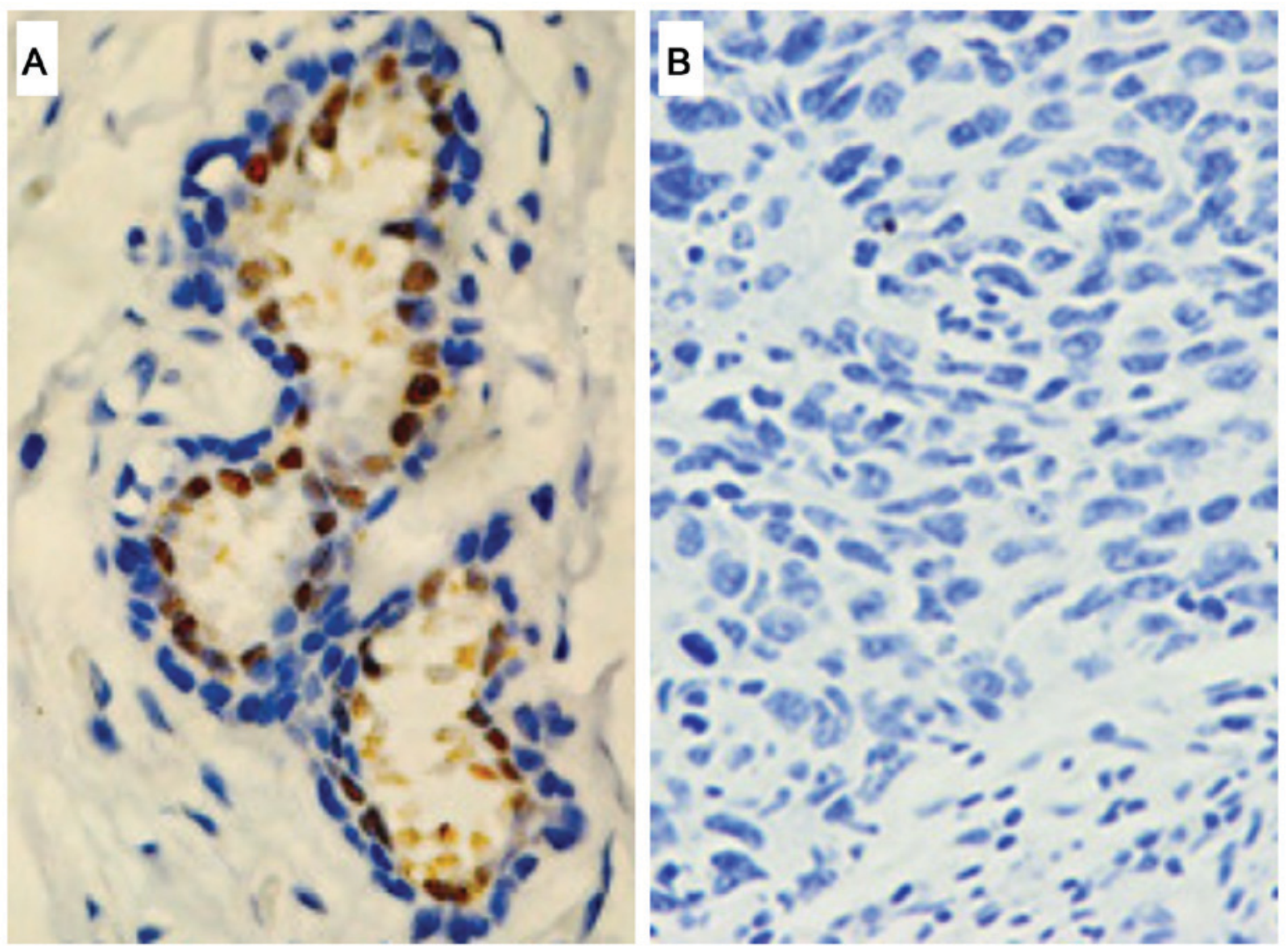

Figure 1. Representative immunohistochemistry images of (A) AR-positive and (B) AR-negative tissue sections (magnification, x400) of patients with triple negative breast cancer. AR, androgen receptor.

AR expression predicts a poor prognosis for stage III TNBC. Whether AR expression was associated with patient prognosis was then investigated. A total of 188 patients were followed-up for up to 60 months, with 37 developing recurrent diseases and 10 succumbing to breast cancer-associated mortality. Kaplan-Meier survival analysis with a log-rank test was performed to assess the association between AR expression and patient survival. In AR-positive patients, the recurrence rate was $19.5 \%$ (8/41), which was similar to $19.7 \%$ (29/147) in AR-negative patients. During this period, the mortality in $\mathrm{AR}^{+} \mathrm{TNBC}$ was $9.76 \%$ (4/41) and the mortality in ARTNBC was $4.08 \%$ (6/147). The results indicated no significant correlation of AR expression with the disease-free and overall survivals of patients (Fig. 2A and B). However, AR expression in stage III tumors (10/61 stage III cases) predicted a poor survival of the patients (Fig. 2C; $\mathrm{P}=0.035$ ) compared with those with no AR positivity (51 patients). In stage III tumors, the mortality in $\mathrm{AR}^{+} \mathrm{TNBC}$ was $30 \%(3 / 10)$ and the mortality in AR-TNBC was 7.8\% (4/51). Among 127 stage I-II patients AR expression was not associated with the survival of patients with early stage of cancer (data not shown).

DFS is associated with age of patients and clinical stage of disease. Univariate and multivariate analyses were performed using 188 patients to identify crucial factors for DFS. Age $>50$ and clinical stage III were identified to be major risk factors for reduced DFS compared with a younger age and early stages, respectively, by univariate and multivariate analyses (Table IV). Lymph node metastasis was also a risk factor for shorter DFS based on univariate analysis (Table IV). Advanced clinical stage was also significantly associated with reduced OS based on univariate and multivariate analyses.

\section{Discussion}

Androgen receptor mediates key processes in mammary gland development, including ductal branching, formation of the milk-producing alveoli and lobuloalveolar development (13). Accumulating evidence highlights its crucial functions in cancer progression (7,28-30). In the present study, the expression of AR in 188 patients with TNBC was determined using immunohistochemistry and its potential value in predicting the prognosis of patients with TNBC treated with NAC was assessed. The results of the present study demonstrated that AR expression was induced by NAC treatment and that AR expression in advanced-stage tumors predicts a poor prognosis in patients with TNBC.

The immunohistochemistry data indicated that $21.8 \%$ of the $188 \mathrm{TNBC}$ cases are positive for AR. This is consistent with previous findings that $10-53 \%$ TNBC tumors express AR (21,31-34). The significant variations between different studies are attributable to a lack of commonly accepted standards and analytical protocols to determine the expression of AR by immunohistochemistry. Since AR is not recognized as 
Table II. Association between chemotherapeutic effect and clinicopathologic characteristics in 102 patients with TNBC.

Chemotherapeutic effect

\begin{tabular}{|c|c|c|c|c|}
\hline \multirow{2}{*}{ Characteristics } & & & \multirow[b]{2}{*}{$\chi^{2}$} & \multirow{2}{*}{ P-value } \\
\hline & pCR (\%) & Non-pCR (\%) & & \\
\hline \multicolumn{5}{|l|}{ Age (years) } \\
\hline$\leq 50$ & $11(18.3)$ & $49(81.7)$ & 0.291 & 0.589 \\
\hline$>50$ & $6(14.3)$ & $36(85.7)$ & & \\
\hline \multicolumn{5}{|l|}{ Menstrual status } \\
\hline Pre-menopause & 13 (18.6) & $57(81.4)$ & 0.583 & 0.445 \\
\hline Post-menopause & $4(12.5)$ & $28(87.5)$ & & \\
\hline \multicolumn{5}{|l|}{ BMI } \\
\hline$<24$ & $5(7.8)$ & $59(92.2)$ & 9.697 & 0.002 \\
\hline$\geq 24$ & $12(31.6)$ & $26(68.4)$ & & \\
\hline \multicolumn{5}{|l|}{ Family history } \\
\hline No & $15(17.9)$ & $69(82.1)$ & 0.486 & 0.730 \\
\hline Yes & $2(11.1)$ & $16(88.9)$ & & \\
\hline \multicolumn{5}{|l|}{ Tumor grade } \\
\hline I-II & 15 (19.7) & $61(80.3)$ & 2.023 & 0.226 \\
\hline III & $2(7.7)$ & $24(92.3)$ & & \\
\hline \multicolumn{5}{|l|}{ Tumor size (cm) } \\
\hline$\leq 5$ & $10(14.5)$ & $59(85.5)$ & 0.726 & 0.394 \\
\hline$>5$ & $7(21.2)$ & $26(78.8)$ & & \\
\hline \multicolumn{5}{|c|}{ Lymph node metastasis } \\
\hline No & $6(16.2)$ & $31(83.8)$ & 0.008 & 0.927 \\
\hline Yes & $11(16.9)$ & $54(83.1)$ & & \\
\hline \multicolumn{5}{|l|}{ Clinical stage } \\
\hline I-II & $10(18.9)$ & $43(81.1)$ & 0.385 & 0.535 \\
\hline III & $7(14.3)$ & $42(85.7)$ & & \\
\hline \multicolumn{5}{|l|}{$\mathrm{AR}$} \\
\hline Negative & $12(14.6)$ & $70(85.4)$ & 1.244 & 0.316 \\
\hline Positive & $5(25.0)$ & $15(75.0)$ & & \\
\hline \multicolumn{5}{|l|}{$\mathrm{Ki}-67$} \\
\hline$<14$ & $3(13.0)$ & $20(87.0)$ & 0.281 & 0.756 \\
\hline$\geq 14$ & $14(17.7)$ & $65(82.3)$ & & \\
\hline
\end{tabular}

TNBC, triple negative breast cancer; AR, androgen receptor; pCR, pathological complete responses.

a prognostic molecule marker in breast cancer, ER is usually assessed instead (35). Furthermore, the thresholds for ER and HER2 expressions in the American Society of Clinical Oncology/College of American Pathologists guideline have been changed $(25,35)$, which resulted in significant decreases in the number of TNBC diagnoses. In the present study, all TNBC cases were diagnosed following the most recent guideline recommendations for the evaluation of ER, PR, AR and HER-2 $(25,35)$. Furthermore, patients with TNBC of various ethnic backgrounds may express AR at different levels, with previous meta-analysis demonstrating that AR expression was slightly increased in Asians when compared with Caucasians (36).

The results of the present study suggested that AR is detected more often in smaller tumors or in cases with no lymph node metastases. This is consistent with previous findings that $\mathrm{AR}^{+}$ carcinomas were highly differentiated and had a low Ki-67 labeling index $(33,34,37,38)$. In preclinical experiments, AR had an anti-proliferative effect through stimulating the expression of ER $\beta$, which inhibited cell growth (39), and AR has been demonstrated to mediate signaling pathways, including Janus kinase/signal transducer and activator of transcription 3, microtubule affinity regulating kinase, NOTCH and phosphatidylinositol 3-kinase (PI3K)/mechanistic target of rapamycin kinase (mTOR)/AKT serine/threonine kinase (40). The multifaceted roles of AR in TNBC implicate that it may be a useful clinical marker.

No significant association was identified between AR expression and the response to NAC in the present study although a lower $\mathrm{pCR}$ rate has previously been demonstrated in $\mathrm{AR}^{+}$compared with $\mathrm{AR}^{-}$patients (41). This may be due to the limited number of $\mathrm{AR}^{+}$cases treated with NAC in the present 
Table III. Association between AR status and NAC in 49 patients with TNBC.

AR status prior to NAC

\begin{tabular}{lcccc}
\cline { 2 - 4 } AR status following NAC & Positive (\%) & Negative (\%) & $\chi^{2}$ & P-value \\
\hline Positive & $6(28.6)$ & $15(71.4)$ & 6.772 & 0.008 \\
Negative & $3(10.7)$ & $25(89.3)$ & & \\
\hline
\end{tabular}

$\mathrm{AR}$, androgen receptor; TNBC, triple negative breast cancer; NAC, neoadjuvant chemotherapy.
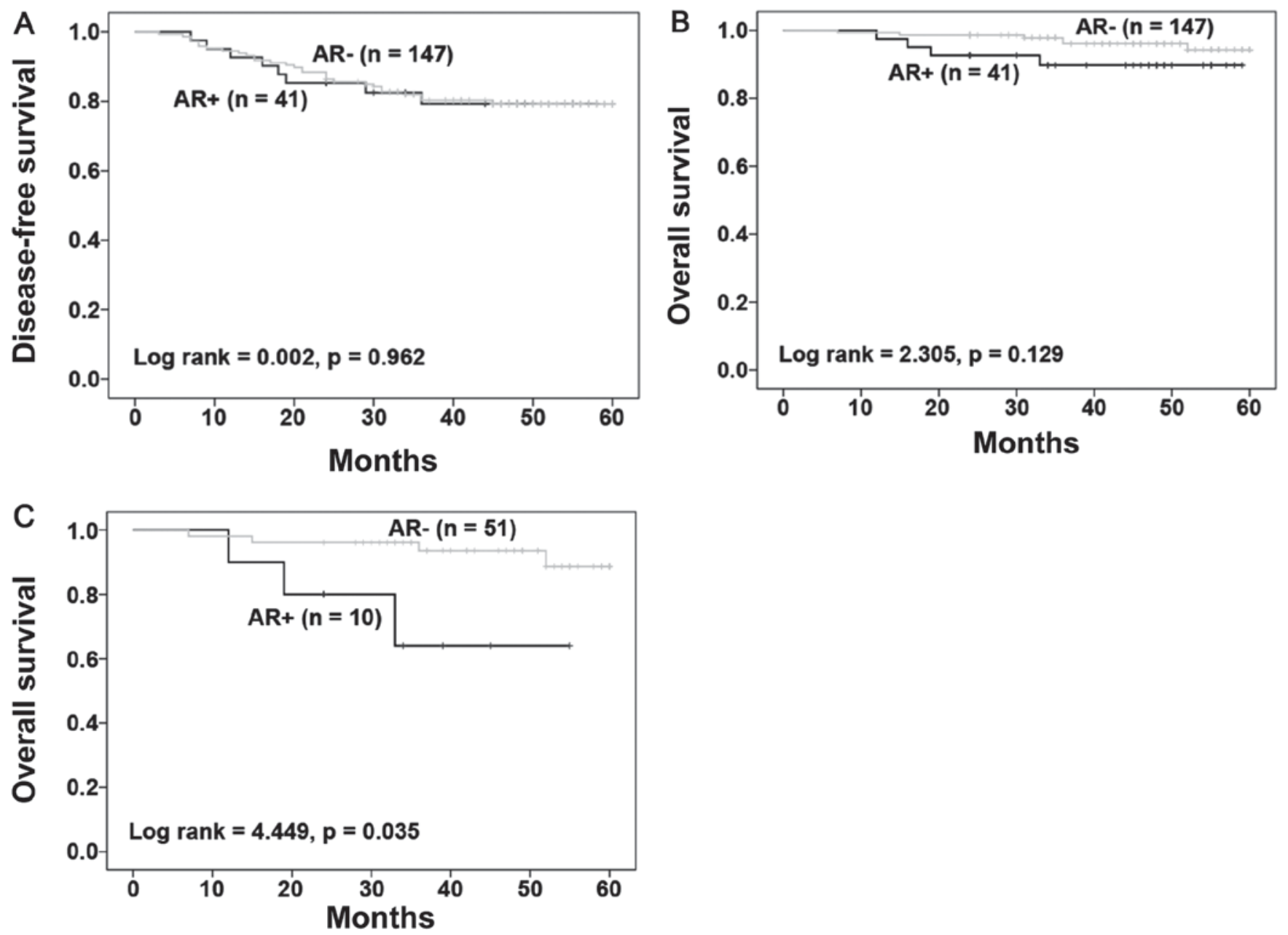

Figure 2. Kaplan-Meier analysis of (A) disease-free and (B) overall survival of 188 patients with triple negative breast cancer stratified by AR expression. (C) Overall survival of 61 patients with stage III tumors subgrouped based on AR positivity. AR, androgen receptor.

study. Also, NAC induced AR expression in certain patients with TNBC, which is likely due to a lower susceptibility of $\mathrm{AR}^{+}$cells to NAC when compared with $\mathrm{AR}^{-}$cells in the present study. A hypothesis is that chemotherapy drugs kill more $\mathrm{AR}^{-}$cells than $\mathrm{AR}^{+}$cells, resulting in the upregulation of $\mathrm{AR}$ gene expression and $\mathrm{AR}^{+}$cells exhibiting chemotherapeutics resistance (42), thus hormone receptor negative breast cancer are more likely to benefit from chemotherapy. Chemotherapy insensitive or resistant triple-negative breast cancer may have high levels of AR expression; therefore, AR-directed therapy may be used in $\mathrm{AR}^{+} \mathrm{TNBC}$, which poorly responds to chemotherapy.

No consistent findings have been reported regarding the association between AR expression and patient survival. While AR expression predicts better OS and DFS in general breast cancer or patients with TNBC (41,43-45), there are also reports that AR positivity is associated with poor prognosis $(34,46-48)$ or is irrelevant to patient survival (37). The results of the present study demonstrated no significant association between AR expression with the survival of 188 patients with TNBC 
Table IV. Univariate and multivariate analysis of disease-free survival in 188 patients with TNBC.

\begin{tabular}{|c|c|c|c|c|c|c|}
\hline \multirow[b]{2}{*}{ Parameters } & \multicolumn{2}{|c|}{ Univariate } & \multirow[b]{2}{*}{ P-value } & \multicolumn{2}{|c|}{ Multivariate } & \multirow[b]{2}{*}{ P-value } \\
\hline & HR & $95 \% \mathrm{CI}$ & & HR & $95 \% \mathrm{CI}$ & \\
\hline Age ( $>50$ years vs. $\leq 50$ years) & 2.007 & $1.041-3.870$ & 0.038 & 2.003 & $1.030-3.896$ & 0.041 \\
\hline Tumor grade (III vs. I-II) & 1.490 & $0.759-2.926$ & 0.247 & 1.538 & $0.781-3.029$ & 0.213 \\
\hline Tumor size $(>5 \mathrm{~cm}$ vs. $\leq 5 \mathrm{~cm}$ ) & 1.258 & $0.594-2.666$ & 0.549 & 0.700 & $0.291-1.687$ & 0.427 \\
\hline Lymph node metastasis (Yes vs. no) & 2.350 & $1.181-4.678$ & 0.015 & 1.783 & $0.808-3.935$ & 0.152 \\
\hline Clinical stage (III vs. I-II) & 2.502 & $1.312-4.770$ & 0.005 & 2.378 & $1.029-5.497$ & 0.043 \\
\hline AR (Positive vs. negative) & 1.019 & $0.466-2.229$ & 0.962 & 1.272 & $0.572-2.828$ & 0.555 \\
\hline Ki-67 ( $\geq 14$ vs. $<14)$ & 1.677 & $0.699-4.023$ & 0.247 & 1.488 & $0.614-3.603$ & 0.379 \\
\hline
\end{tabular}

TNBC, triple negative breast cancer; HR, hazard ratio; CI, confidence interval; AR, androgen receptor.

without stratification. The contradictory conclusions warrant future multi-institutional studies, in which universal standards should be used in the examination of AR expression and the definition of TNBC. However, $\mathrm{AR}^{+}$status was significantly associated with poor overall survival of stage III patients, suggesting the prognostic value of AR for patients with advanced stage TNBC. This result is consistent with previous findings that $\mathrm{AR}^{+} \mathrm{TNBC}$ cells are chemoresistant (42). In ER-negative TNBC, AR stimulates tumor growth by activating the ER signaling pathway (49). As with the molecular apocrine profile $\left(\mathrm{ER}^{-}, \mathrm{AR}^{+}\right)$, it exhibits a high invasive ability and poor prognosis (50). A total of $90 \%$ of patients with TNBC have gene mutations, deletions or amplifications (23), consequently the mechanism of AR in TNBC is not clearly understood.

Prostate cancer is the second most prevalent cancer among males worldwide and it is also a hormone dependent cancer (2). Androgens stimulate the occurrence and development of TNBC molecular by binding AR, and the modulation of androgen levels can be effective in the treatment of prostate cancer (51). Therefore, AR-directed therapy may be effective in a specific group of patients, those with $\mathrm{AR}^{+} \mathrm{TNBC}$, which may increase survival rates. As bicalutamide treatment gains great success in prostate cancer (52),numerous preclinical or clinical studies are committed to the application of AR antagonists in TNBC (53-57). LAR breast cancer cell lines are sensitive to AR antagonists. Furthermore, the study of Cuenca-Lopez et al (53) reported that $\mathrm{AR}^{+} \mathrm{TNBC}$ cell line, which did not belong to the LAR subtype, also had a sensitivity to $\mathrm{AR}$ inhibition. In early clinical trials, patients with advanced $\mathrm{AR}^{+}$ TNBC were treated with bicalutamide with a clinical benefit rate of $20 \%$ (54). In a phase II clinical trial of enzalutamide, which has a six-fold higher affinity to AR than previous bicalutamide, $42 \%$ patients with advanced $\mathrm{AR}^{+} \mathrm{TNBC}$ attained a clinical benefit time of 16 weeks in preliminary data (55). Subsequently, cytochrome P450 enzyme inhibitors, including abiraterone acetate, act on microsomal enzyme to suppress androgen production (56). The study of O'Shaughnessy et al (57), identified that in post-menopausal women with letrozole-pretreated metastatic $\mathrm{ER}^{+}$ breast cancer, combining abiraterone acetate with exemestane did not improve progression free survival compared with treatment with single exemestane.

Selective androgen receptor modulators (SARMs) are novel AR-directed therapies, which have high specificity for AR without masculinizing side effects. Additionally, SARMs improve the side effects of advanced breast cancer by increasing muscle mass and restoring bone mineral density (58). GTx-024 is the one of the precedent SARMs (59). At present, there are a number of drugs about TNBC currently undergoing clinical trials. Nevertheless, an absence of adequate evidence has resulted in these drugs requiring approval. The combination therapy of TNBC may be considered due to the involvement of AR-mediation in numerous signaling pathways. The study of Lehmann et al (24), discovered that in $\mathrm{AR}^{+} \mathrm{TNBC}$ cells, PI3K/mTOR inhibitors in combination with an AR antagonist had an additive growth inhibitory effect. The present study merely discussed AR expression and its relation to survival time in TNBC. Whether AR will function as a therapeutic target is subject to the outcome of clinical trials.

In the 188 patients with TNBC evaluated in this study, AR was expressed in $21 \%$ of them, most often in small nodules or tumors with no lymph node metastases. AR expression does not determine the outcome of NAC; however, NAP may be enriched during chemotherapeutic treatment. The results of the present study suggest that AR expression has potential prognostic value in the prognosis of TNBC, but is limited to patients in the advanced stage of disease.

\section{Acknowledgements}

The authors would like to thank the members of Breast Cancer Prevention and Clinical Research Center (Changsha, China) for data collection.

\section{Funding}

The present study was funded by the National Natural Science Foundation of China for Young Scholar (grant no. 81302289) and Breast Cancer Clinical Medical Technology Research Center in Hunan Province (grant no. 2010TP4053).

\section{Availability of data and materials}

All data generated or analyzed during this study are included in this published article. 


\section{Author contributions}

LT and $\mathrm{KZ}$ conceived and designed the experiments. YL performed the experiments and analyzed data. LT, KZ and YL provided final approval of the manuscript.

\section{Ethical approval and consent to participate}

All procedures performed in studies involving human participants were in accordance with the ethical standards of the institutional and/or national research committee and with the 1964 Helsinki declaration and its later amendments or comparable ethical standards. Informed consent was obtained from all individual participants included in the study.

\section{Consent for publication}

Written informed consent was obtained from all patients to publish their data and accompanying images.

\section{Competing interests}

The authors declare that they have no competing interests.

\section{References}

1. Torre LA, Bray F, Siegel RL, Ferlay J, Lortet-Tieulent J and Jemal A Global cancer statistics, 2012. CA Cancer J Clin 65: 87-108, 2015.

2. Siegel RL, Miller KD and Jemal A: Cancer statistics, 2018. CA Cancer J Clin 68: 7-30, 2018

3. Arnedos M, Vicier C, Loi S, Lefebvre C, Michiels S, Bonnefoi H and Andre F: Precision medicine for metastatic breast cancer-limitations and solutions. Nat Rev Clin Oncol 12: 693-704, 2015.

4. Cancer Genome Atlas Network: Comprehensive molecular portraits of human breast tumours. Nature 490: 61-70, 2012.

5. Lumachi F, Santeufemia DA and Basso SM: Current medical treatment of estrogen receptor-positive breast cancer. World J Biol Chem 6: 231-239, 2015.

6. Ross JS, Slodkowska EA, Symmans WF, Pusztai L, Ravdin PM and Hortobagyi GN: The HER-2 receptor and breast cancer: Ten years of targeted anti-HER-2 therapy and personalized medicine. Oncologist 14: 320-368, 2009.

7. Lehmann BD, Bauer JA, Chen X, Sanders ME, Chakravarthy AB, Shyr Y and Pietenpol JA: Identification of human triple-negative breast cancer subtypes and preclinical models for selection of targeted therapies. J Clin Invest 121: 2750-2767, 2011.

8. Steward L, Conant L, Gao F and Margenthaler J: Predictive factors and patterns of recurrence in patients with triple negative breast cancer. Ann Surg Oncol 21: 2165-2171, 2014.

9. Hassett MJ, O'Malley AJ, Pakes JR, Newhouse JP and Earle CC: Frequency and cost of chemotherapy-related serious adverse effects in a population sample of women with breast cancer. J Natl Cancer Inst 98: 1108-1117, 2006.

10. Liedtke C, Mazouni C, Hess KR, André F, Tordai A, Mejia JA, Symmans WF, Gonzalez-Angulo AM, Hennessy B, Green M, et al: Response to neoadjuvant therapy and long-term survival in patients with triple-negative breast cancer. J Clin Oncol 26: 1275-1281, 2008 .

11. Shang Y, Myers $M$ and Brown M: Formation of the androgen receptor transcription complex. Mol Cell 9: 601-610, 2002.

12. McNamara KM, Moore NL, Hickey TE, Sasano H and Tilley WD: Complexities of androgen receptor signalling in breast cancer. Endocr Relat Cancer 21: T161-T181, 2014

13. Yeh S, Hu Y, Wang P, Xie C, Xu Q, Tsai M, Dong Z, Wang R, Lee $\mathrm{T}$ and Chang $\mathrm{C}$ : Abnormal mammary gland development and growth retardation in female mice and MCF7 breast cancer cells lacking androgen receptor. J Exp Med 198: 1899-1908, 2003.

14. Niemeier LA, Dabbs DJ, Beriwal S, Striebel JM and Bhargava R: Androgen receptor in breast cancer: Expression in estrogen receptor-positive tumors and in estrogen receptor-negative tumors with apocrine differentiation. Mod Pathol 23: 205-212, 2010.
15. Park S, Koo JS, Kim MS, Park HS, Lee JS, Lee JS, Kim SI, Park BW and Lee KS: Androgen receptor expression is significantly associated with better outcomes in estrogen receptor-positive breast cancers. Ann Oncol 22: 1755-1762, 2011.

16. Goldenberg IS: Testosterone propionate therapy in breast cancer. JAMA 188: 1069-1072, 1964

17. Garay JP and Park BH: Androgen receptor as a targeted therapy for breast cancer. Am J Cancer Res 2: 434-445, 2012.

18. Chia K, O'Brien M, Brown M and Lim E: Targeting the androgen receptor in breast cancer. Curr Oncol Rep 17: 4, 2015.

19. Fujii R, Hanamura T, Suzuki T, Gohno T, Shibahara Y, Niwa T, Yamaguchi Y, Ohnuki K, Kakugawa Y, Hirakawa H, et al: Increased androgen receptor activity and cell proliferation in aromatase inhibitor-resistant breast carcinoma. J Steroid Biochem Mol Biol 144: 513-522, 2014.

20. Maugeri-Saccà M, Barba M, Vici P, Pizzuti L, Sergi D, De Maria R and Di Lauro L: Aromatase inhibitors for metastatic male breast cancer: Molecular, endocrine, and clinical considerations. Breast Cancer Res Treat 147: 227-235, 2014.

21. Qi JP, Yang YL, Zhu H, Wang J, Jia Y, Liu N, Song YJ, Zan LK, Zhang X, Zhou M, et al: Expression of the androgen receptor and its correlation with molecular subtypes in 980 chinese breast cancer patients. Breast Cancer (Auckl) 6: 1-8, 2012.

22. McNamara KM, Yoda T, Takagi K, Miki Y, Suzuki T and Sasano H: Androgen receptor in triple negative breast cancer. J Steroid Biochem Mol Biol 133: 66-76, 2013.

23. Xu H, Eirew P, Mullaly SC and Aparicio S: The omics of triple-negative breast cancers. Clin Chem 60: 122-133, 2014.

24. Lehmann BD, Bauer JA, Schafer JM, Pendleton CS, Tang L, Johnson KC, Chen X, Balko JM, Gómez H, Arteaga CL, et al: PIK3CA mutations in androgen receptor-positive triple negative breast cancer confer sensitivity to the combination of PI3K and androgen receptor inhibitors. Breast Cancer Res 16: 406, 2014.

25. Wolff AC, Hammond ME, Hicks DG, Dowsett M, McShane LM, Allison KH, Allred DC, Bartlett JM, Bilous M, Fitzgibbons $\mathrm{P}$, et al: Recommendations for human epidermal growth factor receptor 2 testing in breast cancer: American Society of Clinical Oncology/College of American Pathologists clinical practice guideline update. Arch Pathol Lab Med 138: 241-256, 2014.

26. Shi SR, Guo J, Cote RJ, Young L, Hawes D, Shi Y, Thu S and Taylor CR: Sensitivity and detection efficiency of a novel two-step detection system (PowerVision) for immunohistochemistry. Appl Immunohistochem 7: 201-208, 1999.

27. Eisenhauer EA, Therasse P, Bogaerts J, Schwartz LH, Sargent D, Ford R, Dancey J, Arbuck S, Gwyther S, Mooney M, et al: New response evaluation criteria in solid tumours: Revised RECIST guideline (version 1.1). Eur J Cancer 45: 228-247, 2009.

28. Chia KM, Liu J, Francis GD and Naderi A: A feedback loop between androgen receptor and ERK signaling in estrogen receptor-negative breast cancer. Neoplasia 13: 154-166, 2011.

29. Micello D, Marando A, Sahnane N, Riva C, Capella C and Sessa F: Androgen receptor is frequently expressed in HER2-positive, ER/PR-negative breast cancers. Virchows Arch 457: 467-476, 2010

30. Robinson JL, Macarthur S, Ross-Innes CS, Tilley WD, Neal DE, Mills IG and Carroll JS: Androgen receptor driven transcription in molecular apocrine breast cancer is mediated by FoxA1. EMBO J 30: 3019-3027, 2011.

31. Rakha EA, El-Sayed ME, Green AR, Lee AH, Robertson JF and Ellis IO: Prognostic markers in triple-negative breast cancer. Cancer 109: 25-32, 2007.

32. McNamara KM, Yoda T, Miki Y, Chanplakorn N, Wongwaisayawan S, Incharoen P, Kongdan Y, Wang L, Takagi K, Mayu T, et al: Androgenic pathway in triple negative invasive ductal tumors: Its correlation with tumor cell proliferation. Cancer Sci 104: 639-646, 2013.

33. Thike AA, Yong-Zheng Chong L, Cheok PY, Li HH, Wai-Cheong Yip G, Huat Bay B, Tse GM, Iqbal J and Tan PH: Loss of androgen receptor expression predicts early recurrence in triple-negative and basal-like breast cancer. Mod Pathol 27: 352-360, 2014.

34. Choi JE, Kang SH, Lee SJ and Bae YK: Androgen receptor expression predicts decreased survival in early stage triple-negative breast cancer. Ann Surg Oncol 22: 82-89, 2015.

35. Hammond ME, Hayes DF, Dowsett M, Allred DC, Hagerty KL, Badve S, Fitzgibbons PL, Francis G, Goldstein NS, Hayes M, et al: American Society of Clinical Oncology/College of American Pathologists guideline recommendations for immunohistochemical testing of estrogen and progesterone receptors in breast cancer (unabridged version). Arch Pathol Lab Med 134: e48-e72, 2010 . 
36. Zhang L, Fang C, Xu X, Li A, Cai Q and Long X: Androgen receptor, EGFR, and BRCA1 as biomarkers in triple-negative breast cancer: A meta-analysis. Biomed Res Int 2015: 357485, 2015.

37. Mrklić I, Pogorelić Z, Ćapkun V and Tomić S: Expression of androgen receptors in triple negative breast carcinomas. Acta Histochem 115: 344-348, 2013.

38. Ricciardi GR, Adamo B, Ieni A, Licata L, Cardia R, Ferraro G, Franchina T, Tuccari G and Adamo V: Androgen receptor (AR), E-Cadherin, and Ki-67 as emerging targets and novel prognostic markers in triple-negative breast cancer (TNBC) patients. PloS One 10: e0128368, 2015.

39. Honma N, Horii R, Iwase T, Saji S, Saji S, Younes M, Takubo K, Matsuura M, Ito Y, Akiyama F and Sakamoto G: Clinical importance of estrogen receptor-beta evaluation in breast cancer patients treated with adjuvant tamoxifen therapy. J Clin Oncol 26 : 3727-3734, 2008.

40. Anestis A, Karamouzis MV, Dalagiorgou G and Papavassiliou AG: Is androgen receptor targeting an emerging treatment strategy for triple negative breast cancer? Cancer Treat Rev 41: 547-553, 2015

41. Loibl S, Müller BM, von Minckwitz G, Schwabe M, Roller M, Darb-Esfahani S, Ataseven B, du Bois A, Fissler-Eckhoff A, Gerber B, et al: Androgen receptor expression in primary breast cancer and its predictive and prognostic value in patients treated with neoadjuvant chemotherapy. Breast Cancer Res Treat 130: 477-487, 2011

42. Lehmann BD and Pietenpol JA: Identification and use of biomarkers in treatment strategies for triple-negative breast cancer subtypes. J Pathol 232: 142-150, 2014

43. Luo X, Shi YX, Li ZM and Jiang WQ: Expression and clinical significance of androgen receptor in triple negative breast cancer. Chin J Cancer 29: 585-590, 2010.

44. Gasparini P, Fassan M, Cascione L, Guler G, Balci S, Irkkan C, Paisie C, Lovat F, Morrison C, Zhang J, et al: Androgen receptor status is a prognostic marker in non-basal triple negative breast cancers and determines novel therapeutic options. PLoS One 9 e88525, 2014

45. Vera-Badillo FE, Templeton AJ, de Gouveia P, Diaz-Padilla I, Bedard PL, Al-Mubarak M, Seruga B, Tannock IF, Ocana A and Amir E: Androgen receptor expression and outcomes in early breast cancer: A systematic review and meta-analysis. J Natl Cancer Inst 106: djt319, 2014.

46. Hu R, Dawood S, Holmes MD, Collins LC, Schnitt SJ, Cole K, Marotti JD, Hankinson SE, Colditz GA and Tamimi RM: Androgen receptor expression and breast cancer survival in postmenopausal women. Clin Cancer Res 17: 1867-1874, 2011.

47. Sutton LM, Cao D, Sarode V, Molberg KH, Torgbe K, Haley B and Peng Y: Decreased androgen receptor expression is associated with distant metastases in patients with androgen receptor-expressing triple-negative breast carcinoma. Am J Clin Pathol 138: 511-516, 2012.

48. McGhan LJ, McCullough AE, Protheroe CA, Dueck AC, Lee JJ, Nunez-Nateras R, Castle EP, Gray RJ, Wasif N, Goetz MP, et al Androgen receptor-positive triple negative breast cancer: A unique breast cancer subtype. Ann Surg Oncol 21: 361-367, 2014.
49. Doane AS, Danso M, Lal P, Donaton M, Zhang L, Hudis C and Gerald WL: An estrogen receptor-negative breast cancer subset characterized by a hormonally regulated transcriptional program and response to androgen. Oncogene 25: 3994-4008, 2006.

50. Tsutsumi Y: Apocrine carcinoma as triple-negative breast cancer: Novel definition of apocrine-type carcinoma as estrogen/progesterone receptor-negative and androgen receptor-positive invasive ductal carcinoma. Jpn J Clin Oncol 42: 375-386, 2012.

51. Komura K, Sweeney CJ, Inamoto T, Ibuki N, Azuma H and Kantoff PW: Current treatment strategies for advanced prostate cancer. Int J Urol, 2017.

52. Loblaw DA, Virgo KS, Nam R, Somerfield MR, Ben-Josef E, Mendelson DS, Middleton R, Sharp SA, Smith TJ, Talcott J, et al: Initial hormonal management of androgen-sensitive metastatic, recurrent, or progressive prostate cancer: 2006 update of an American Society of Clinical Oncology practice guideline. J Clin Oncol 25: 1596-1605, 2007.

53. Cuenca-López MD, Montero JC, Morales JC, Prat A, Pandiella A and Ocana A: Phospho-kinase profile of triple negative breast cancer and androgen receptor signaling. BMC Cancer 14: 302, 2014.

54. Gucalp A, Tolaney S, Isakoff SJ, Ingle JN, Liu MC, Carey LA, Blackwell K, Rugo H, Nabell L, Forero A, et al: Phase II Trial of bicalutamide in patients with androgen receptor-positive, estrogen receptor-negative metastatic breast cancer. Clin Cancer Res 19: 5505-5512, 2013.

55. Traina TA, Miller K, Yardley DA, Eakle J, Schwartzberg LS, O'Shaughnessy J, Gradishar W, Schmid P, Winer E, Kelly C, et al: Enzalutamide for the treatment of androgen receptor-expressing triple-negative breast cancer. J Clin Oncol: JCO2016713495, 2018.

56. Attard G, Reid AH, A'Hern R, Parker C, Oommen NB, Folkerd E, Messiou C, Molife LR, Maier G, Thompson E, et al: Selective inhibition of CYP17 with abiraterone acetate is highly active in the treatment of castration-resistant prostate cancer. J Clin Oncol 27: 3742-3748, 2009.

57. O'Shaughnessy J, Campone M, Brain E, Neven P, Hayes D, Bondarenko I, Griffin TW, Martin J, De Porre P, Kheoh T, et al: Abiraterone acetate, exemestane or the combination in postmenopausal patients with estrogen receptor-positive metastatic breast cancer. Ann Oncol 27: 106-113, 2015.

58. Narayanan R, Coss CC and Dalton JT: Development of selective androgen receptor modulators (SARMs). Mol Cell Endocrinol: pii: S0303-7207(17)30340-4, 2017.

59. Narayanan R, Ahn S, Cheney MD, Yepuru M, Miller DD, Steiner MS and Dalton JT: Selective Androgen receptor modulators (SARMs) negatively regulate triple-negative breast cancer growth and epithelial: Mesenchymal stem cell signaling. PLoS One 9: e103202, 2014. 